\section{International Scientific Journal Theoretical \& Applied Science}

p-ISSN: 2308-4944 (print) e-ISSN: 2409-0085 (online)

Year: $2017 \quad$ Issue: $05 \quad$ Volume: 49

Published: 27.05.2017 http://T-Science.org

SECTION 21. Pedagogy. Psychology. Innovations in the field of education.
Valentina Vladimirovna Ignatova

Doctor of pedagogical sciences, professor Reshetnev Siberian State University of Science and Technology, Krasnoyarsk

Tatiana Nickolaevna Pasechkina Teacher of Foreign languages and culture of speech department Siberian Fire Rescue Academy of the Ministry for Emergency Situations of Russia Zheleznogorsk Krasnoyarsk territory pasechkina@yandex.ru

\title{
COMMUNICATIVE SELF-EFFICACY AS THE MOST IMPORTANT QUALITY OF THE FUTURE SPECIALIST
}

\author{
Abstract: The author of the article pays attention to the relevance of "self-efficacy" among students in the \\ educational activities in connection with the new realities of life. It emphasizes the importance of the work on \\ communicative self-efficacy formation. \\ Key words: self-efficacy, communication self-efficacy, self-efficacy structure. \\ Language: English \\ Citation: Ignatova VV, Pasechkina TN (2017) COMMUNICATIVE SELF-EFFICACY AS THE MOST \\ IMPORTANT QUALITY OF THE FUTURE SPECIALIST. ISJ Theoretical \& Applied Science, 05 (49): $161-164$. \\ Soi: http://s-o-i.org/1.1/TAS-05-49-24 Doi: crossef https://dx.doi.org/10.15863/TAS.2017.05.49.24
}

\section{Introduction.}

At present, society is gradually moving from the commodity economy to the intellectual-creative economy. In this context, the mastering of Internet technologies, nano-technologies, and robotics by students is considered as a very important aspect of their professional training and determines their willingness to achieve real success in their future activities. However, this does not mean that there is no need to develop abilities which are inaccessible to robots: creativity, imagination, initiative, communication, leadership qualities. Active life position, serious motivation for the profession, tendency to self-development, stress resistance, business negotiations skills, providing psychological help, conflict resolution, ability to act independently, actively and creatively, ability to navigate in situations of uncertainty in activities and communication, readiness for team work, etc. - these are the main market competencies that currently make university graduates attractive candidates for the proposed positions.

Whatever a person does, he must have a creative approach to everything, a lively imagination, the ability to quickly navigate in changing circumstances and there must be a well-developed intuition.

In this regard, there is a special interest in searching for internal resources, which actualization will lead to the increasing of success and productivity in the process of self-realization of the individual. And, first of all, the belief in the effectiveness of one's own actions and the expectation of success from their realization is very important, that is self-efficacy of the individual.

\section{The main text}

The term "self-efficacy" is one of the main terms in the social-cognitive theory of Albert Bandura. According to the scientist, self-efficacy, or belief in effectiveness, means a person's conviction that in a difficult situation he will be able to demonstrate good behavior [1].

As A. Bandura and other researchers have shown, self-efficacy can influence a wide range of aspects of our life - from the psychological state to behavior and motivation. The scientist also found out that the individual's self-efficacy plays an important role in choosing the ways of achievement of goals, of solution of problems. People with a high level of self-efficacy view complex problems as tasks that will necessarily be resolved; they show a deep interest in the activities they are engaged in; and they recover from failure faster than the others. People with a low level of self-efficacy tend to avoid complex tasks; they are sure that they are not able to cope with them; they focus on their own shortcomings and past failures.

Many foreign and domestic psychologists and educators have been researching the self-efficacy. They've proved that the influence of self-efficacy extends to any human activity. Thus, S.N. Gonchar correlates self-efficacy with ideas about one's own behavior and the results that this behavior gives (selfefficacy in activity), and also with ideas about one's 
own abilities to successfully communicate with others (self-efficacy in communication) [4]. M.I. Gaidar, in turn, identifies three types of self-efficacy: activity self-efficacy - the subject's conviction in the possession of knowledge, skills for meaningful implementation of activities, productive mastery of new forms of behavior; communicative self-efficacy the subject's conviction in the ability to effectively and qualitatively implement communication with the others, as well as in the possession of a wide range of means of communication; personal self-efficacy is an integrative psychological characteristic, a combination of ideas in a human being about the existence of personally important qualities and the belief that the subject can skillfully apply them in different situations, achieving the desired result [3, p.11-12]. J. Maddux and M. Scheer singled out selfefficacy in the subject-matter activity as a confidence that the existing experience, knowledge and skills in a particular activity can be successfully applied in future activity, and self-efficacy in communication as a confidence that interaction with other members of society can have a positive effect on the final result of the activity [6, p.38]. In the T.O. Gordeeva's opinion self-efficacy is "the belief of a subject in his own ability to cope with a certain activity" [5, p. 80]. In this definition, there is a clear connection between the individual's self-efficacy and the practical activity carried out by the individual, through which this quality manifests itself, that is why a scientific study of self-efficacy must take place within the framework of a certain organized activity of the subject.

First of all, we are interested in the question of the formation of communicative competence among students at a university and, as a consequence, the question of orienting future specialists to communicative self-efficacy.

Therefore, we organized a special study among the one-two-year cadets of the Siberian Fire Rescue Academy of the Ministry for Emergency Situations of Russia (specialty "Fire Safety"). The purpose of this study was to explore the self-efficacy of cadets, including communicative self-efficacy.
Observations of cadets in the classes showed that many of them prefer to work independently, rather than cooperate in pairs or groups. They often hesitate to speak in front of their group, some refuse to speak or communicate, making reports (even in Russian) many of them very often cannot take eyes off the text, the information which has been found by cadets is not often structured, and it's hard to listen to them. But the most important conclusion arising from observation is that they do not try to change the situation, they seem even to "hesitate their own selfefficacy."

In order to determine the cadets' level of selfefficacy a special test was done (authors: Maddux and Scheer, modification by L. Boyarintseva, R. Krichevsky) [6, c.38-41], 69 people took part in testing. An analysis of the results showed that overconfidence in the potential for organizing and conducting their own activities necessary to achieve a specific goal was demonstrated by $29 \%$ of cadets, over $46 \%$ of cadets showed excessive confidence in their potential abilities to organize and carry out their own activities necessary to achieve a certain goal; moderately expressed confidence (the average level of self-efficacy) in the subject activity was manifested by $68 \%$ of cadets, in interpersonal communication - 30\%; uncertainty in their own strengths, a weak belief in the availability of potential abilities to organize and carry out their own activities was demonstrated by $3 \%$ of cadets, in the field of interpersonal communication - $23 \%$.

At the same time, we were interested to know the opinion of cadets about what competencies they considered to be the most important for themselves, and whether the mastery of these competencies affected their communicative self-efficacy. The onetwo-year students were offered a list of general cultural competences and general professional competencies, considered in the Federal State Educational Standard of Higher Education in this specialty (20.05.01. "Fire Safety").

The results of the conducted survey are reflected in Table 1.

The results of the survey of cadets

Table 1

\begin{tabular}{|c|c|c|c|c|}
\hline \multirow[t]{2}{*}{ № } & \multirow[t]{2}{*}{ Competence } & \multirow[t]{2}{*}{$\begin{array}{c}\text { Significance } \\
\text { level }\end{array}$} & \multicolumn{2}{|c|}{$\begin{array}{c}\text { Influence on communicative } \\
\text { self-efficacy }\end{array}$} \\
\hline & & & Direct & Indirect \\
\hline 1 & the ability to abstract thinking, analysis, synthesis & 4 & + & \\
\hline 2 & $\begin{array}{l}\text { the ability to use the basics of philosophical knowledge to } \\
\text { form a worldview position. }\end{array}$ & 12 & & + \\
\hline 3 & $\begin{array}{l}\text { the ability to analyze the main stages and patterns of } \\
\text { historical development of society for the formation of a } \\
\text { civil position. }\end{array}$ & 11 & & + \\
\hline 4 & $\begin{array}{l}\text { the ability to use the basics of economic knowledge in } \\
\text { various spheres of life. }\end{array}$ & 9 & + & \\
\hline 5 & the ability to use the basics of legal knowledge in various & 6 & + & \\
\hline
\end{tabular}




\begin{tabular}{|c|c|c|c|c|}
\hline & spheres of life. & & & \\
\hline 6 & $\begin{array}{l}\text { the readiness to act in non-standard situations, to bear } \\
\text { social and ethical responsibility for the decisions. }\end{array}$ & 1 & + & \\
\hline 7 & $\begin{array}{l}\text { the readiness to self-development, self-realization, using } \\
\text { creative potential. }\end{array}$ & 8 & + & \\
\hline 8 & $\begin{array}{l}\text { the ability to use methods and means of physical culture to } \\
\text { ensure full social and professional activities . }\end{array}$ & 3 & & + \\
\hline 9 & $\begin{array}{l}\text { the ability to use first-aid techniques, methods of protection } \\
\text { in emergency situations. }\end{array}$ & 2 & + & \\
\hline 10 & $\begin{array}{l}\text { the ability to solve problems of professional activity on the } \\
\text { basis of information and bibliographic culture using } \\
\text { information and communication technologies and taking } \\
\text { into account the basic information security requirements. }\end{array}$ & 7 & + & \\
\hline 11 & $\begin{array}{l}\text { the readiness for communication in oral and written forms } \\
\text { in Russian and foreign languages to decide different tasks } \\
\text { of professional activities. }\end{array}$ & 5 & + & \\
\hline 12 & $\begin{array}{l}\text { the readiness to lead the team in the sphere of their } \\
\text { professional activity, tolerate social, ethnic, confessional } \\
\text { and cultural differences. }\end{array}$ & 10 & + & \\
\hline
\end{tabular}

Analysis of the results of the survey shows that the competence considered by cadets as the most important are connected with the willingness to act in unusual situations, as well as with the willingness to communicate in various forms to solve problems of professional activity. Moreover, in the opinion of cadets, most of the general cultural and general professional competences of the future specialist are directly related to such quality as communicative self-effectiveness.

Thus, based on the analysis of the results of observation, testing and the survey, as well as in the process of joint discussion with cadets, we came to the conclusion that self-efficacy, including communicative self-efficacy, is a super quality of a person, which is necessary for a modern graduate of the university as it determines person competitiveness.

Therefore, it is important to organize a purposeful work on the development of communicative self-efficacy of cadets. We believe that orienting the students to communicative selfefficacy is the most optimal pedagogical strategy in this case, since it involves a set of pedagogical activities of an introductory, recommendatory, supportive nature that help to give a value to the work being done [7, p.16].

As S.V. Bogomazov puts it, self-efficacy can be measured quantitatively and changed due to external or internal influence [2, p.30]. Therefore, talking about the change, the impact on the self-efficacy of a person, one must clearly understand its structure.

We've studied the literature on this issue and singled out the following components of communicative self-efficacy:

- value-motivational component (as I refer to my own communicative self-efficacy): the need to master the communication culture; understanding of the value of effective communication, orientation to the forthcoming communicative activity and mastering of communicative experience;

- cognitive-reflective component (what I know about my own communicative self-efficacy): ideas about the essence of communicative self-efficacy and how to build my communicative activity; reflection on the subject of what I can, what I do not know, how to work on, the ability to carry out an independent search for necessary information in situations of uncertainty;

- the activity-regulative component (which communication strategies I choose to solve problems in situations of uncertainty): demonstration of my own achievements, competence in the field of communication; verbal self-hypnosis, conviction in the upcoming success, evaluation of one's own communicative behavior and changing it to more effective according to the situation.

\section{Summary and Conclusions.}

We considered self-efficacy including communicative self-efficacy as a super quality of a person, which is necessary for a modern graduate of the university as it determines person competitiveness. Having studied special literature we can conclude that self-efficacy means the ability of a person to cope with specific and complex situations and to influence the effectiveness of their own activities. A person who has realized his own selfefficacy, i.e. a person focused on self-efficacy in communicative activity, makes more efforts to solve complex problems than that person who doubts about his capabilities.

Obviously, for full-fledged orientation of students to communicative self-efficacy in the educational process in university, it is necessary to create conditions of a strategic nature, each of which, according to the logic of the pedagogical process, corresponds to the named components. The impact on each component of the structure of 


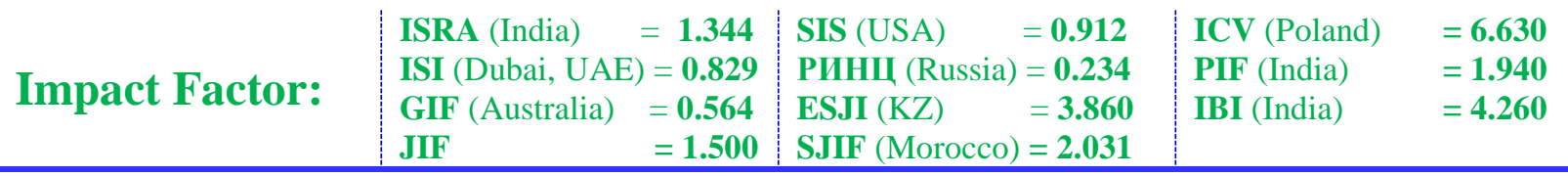

communicative self-efficacy through the creation of strategic conditions in the educational acquisition process of the university will facilitate to getting by students of new meanings of communicative selfefficacy; to formation of attitude to the change of its qualitative and quantitative characteristics; to manifestation, enrichment of personal experience of communicative self-efficacy and other.

\section{References:}

1. Bandura A (2000) Teoriya social'nogo naucheniya. - SPb. : Evraziya. - 320 p.

2. Bogomazov SV (2016) Stanovlenie tvorcheskoj samoehffektivnosti budushchego bakalavra $\mathrm{V}$ informacionno-poiskovoj deyatel'nosti: dis. kand. ped. nauk.-Krasnoyarsk. - 284 p.

3. Gajdar MI (2008) Razvitie lichnostnoj samoehffektivnosti studentov-psihologov na ehtape vuzovskogo obucheniya: Avtoref. dis. kand. psih. nauk. - Kursk. -27 p.

4. Gonchar SN (2012) Samoehffektivnost' kak professional'noe kachestvo budushchih pedagogov-psihologov // Pedagogicheskoe masterstvo: materialy Mezhdunar. nauch. konf. (g. Moskva, aprel' 2012 g.). — M.: Buki-Vedi. - p. 250-253.

5. Gordeeva TO, Shepeleva EA (2006) Tendernye razlichiya $\mathrm{V}$ akademicheskoj i social'noj samoehffektivnosti i koping - strategiyah u sovremennyh rossijskih podrostkov // Vesti Mosk.un - ta. Ser. 14, Psihologiya. - 2006. - № 3. - p. $78-85$.

6. Krasnoryadceva OM, Kabrin VI, Murav'eva OI, et al. (2014) Psihologicheskie praktiki diagnostiki i razvitiya samoehffektivnosti studencheskoj molodezhi :ucheb. posobie. Tomsk : Izdatel'skij Dom TGU, 2014. - p.3841.

7. (2015) Pedagogicheskie strategii stanovleniya lichnosti v sociokul'turnom obrazovatel'nom prostranstve / pod obshch. red. dokt. ped. nauk, prof. V.V. Ignatovoj.-Krasnoyarsk: Izd-vo SibGTU. - 274 p.

8. Selezneva EV (2016) Samoehffektivnost' kak akmeologicheskij invariant professionalizma kadrov upravleniya //Akmeologiya. - 2016. №2. [EHlektronnyj resurs] Available http://akmeology.ru/data/documents/2016Akmeologiya-Obrazec-rukopisi.pdf (Accessed: 10.05.2017)

9. (2005) Sovremennaya psihologiya truda: uchebnoe posobie /V.A.Tolochek. - SPb. : Piter, 2005. - 479 p.

10. Shkuratova IP, Gabdulina LI (1998) Polezavisimost'-polenezavisimost' kak determinanta individual'no-stilevyh osobennostej pedagogicheskogo obshcheniya // Psihologicheskij vestnik. - Rostov-na-Donu.1998. - № 3. - p. 226-235. 